\title{
THE EFFECT OF DECENTRALIZATION ON THE HEALTH STATUS AND HEALTH CARE UTILIZATION PATTERNS IN INDONESIA
}

\author{
Robert Tilden ${ }^{1}$; Ascobat Gani1 ${ }^{12}$; Nur Nasry Noor'; RM. Widjajanto' dan James Sonnemann ${ }^{1}$ \\ ${ }^{1}$ Team Technical Assistance Decentralized Health Project I \\ ${ }^{2}$ Fakultas Kesehatan Masyarakat, Universitas Indonesia, Jakarta
}

\begin{abstract}
ABSTRAK
Berbagai indikator pelayanan dan status kesehatan berdasakan tingkat pengeluaran konsumsi rumahtangga menurut quintile sebelum dan sesudah desentralisasi dinilai dan dikaji. Dilakukan juga penilaian perubahan status kesehatan pada periode desentralisasi, dan juga perbandingan antar wilayah yang menerima dan melaksanakan berbagai program pelayanan kesehatan atau wilayah yang tidak sama sekali mendapatkan inisiasi program pelayanan kesehatan. Data Susenas 2000 dan 2004 digunakan untuk menilai perubahan berbagai indikator kesehatan: morbiditas, pelayanan rawat jalan dan rawat inap, pelayanan kehamilan dan melahirkan, dan status gizi balita sebelum dan sesudah desentralisasi dilaksanakan. Perubahan rasio kematian bayi, kematian ibu, serta kematian balita juga termasuk analisis dari kajian ini. Seluruh analisis dilakukan pembobotan populasi dan analisa statistik dilakukan menggunakan SpssPC (rev 12). Dari hasil kajian menunjukkan bahwa terjadi sedikit peningkatan yang cukup berarti dari kejadian penyakit atau morbiditas penduduk antara tahun 2000 dan 2004, akan tetapi pemanfaatan pelayanan kesehatan (rawat jalan) meningkat di fasilitas pemerintah atau swasta. Peningkatan terbesar terjadi juga pada pelayanan kesehatan rawat inap. Dilaporkan juga pada tahun 2004 hanya sedikit sekali penyakit ditemukan oleh pelayanan kesehatan. Kajian ini juga menemukan bahwa sebelum dan sesudah desentralisasi, penggunaan pelayanan kesehatan terbanyak tetap dilakukan pada kelompok penduduk kaya. Provinsi yang mendapat tambahan biaya dari pinjaman menunjukkan penggunaan fasilitas pelayanan kesehatan yang meningkat terutama untuk pasien rawat jalan. Ada kecenderungan angka kematian balita menurun walaupun status gizi pada balita tidak mengalami perubahan atau peningkatan. Angka kematian bayi menurun cukup signifikan semenjak desentralisasi demikian juga kematian ibu. Terlihat jelas bahwa investasi pelayanan kesehatan yang nampaknya tidak menjadi prioritas pemerintah maupun masyarakat Indonesia. Sebelum dan sesudah desentralisasi Indonesia merupakan negara dimana investasi untuk pelayanan kesehatan menduduki urutan terendah dibandingkan dengan negara lain di dunia ini, terutama negara di ASEAN. Status kesehatan di Indonesia dapat dikatakan membaik walaupun kesepakatan pemerintah untuk memberikan alokasi kesehatan sangat rendah. Perubahan status kesehatan yang terjadi pada masa desentralisasi sebenarnya juga merupakan hasil dari kebijakan yang telah dilakukan sebelum desentralisasi. Selain itu, determinan kesehatan tidak selalu karena pendanaan dalam sistem kesehatan saja akan tetapi bisa saja berkaitan dengan sektor lain seperti pendidikan, dan pendapatan. Desentralisasi namapaknya tidak memberikan konsekuensi negatif terhadap memburuknya status kesehatan di Indonesia. Bahkan, beberapa indikator kesehatan terlihat membaik denagn perubahan lebih cepat pada saat desentaralisasi diibanding sebelumnya. Terutama pada provinsi dimana sosialisasi inisiatif sektor kesehatan diperkenalkan dengain menggunakan dukungan multilateral, terlihat terjadi peningkatan penggunaan pelayanan kesehatan, terutama pelayanan kelahiran dan peningkatan status kesehatan. Hanya gizi kurang pada balita yang nampaknya tidak membaik pada 10 tahun terakhir, kecuali membaik hanya pada saat adanya bantuan pada masa krisis moneter.
\end{abstract}

Keywords: Decentralization, Health Sector Reform, Health Impact 



\section{BACKGROUND}

Decentralization has been promoted by many political scientists as enabling local populations in the political process, and helping improve the responsiveness of governments to local needs and aspirations ${ }^{1}$. However it is also seen as having potential threat to various social programs as health care and education ${ }^{2}$.

In 1999 the Indonesian parliament passed two laws to promote decentralization (Law 22 and Law 25 of 1999), which redefined government function, and finance, which gave district governments large responsibility in allocating resources for the social sector. There was some concern at that time, that health, already an area with low levels of investment in Indonesia, might be even more seriously impacted if local governments spent more money on local infrastructure, or increase salaries to local government officials, than invest in health.
Under the old centralist system, when health care was funded nationally, medical care centers were seen as revenue generating sources for local government. However after financial responsibility for the public health system was delegated to the district government to support, public health was in competition with other social sectors, and development plans.

Indonesia has one of the lowest levels of health expenditure in the ASEAN region, this is true rather one is comparing in absolute levels or as a percentage of GDP, or as a percentage of government expenditures. Yet none of the ASEAN countries spend nearly as much as Europe or North American Countries. 
Table 1

Health Care expenditures in Select ASEAN countries as total Amount, and Percentage of the $\mathrm{GDP}^{3}$

\begin{tabular}{|l|c|c|c|c|c|}
\hline \multicolumn{1}{|c|}{ Country } & $\begin{array}{c}\text { Per capita Health } \\
\text { Expenditure } \\
\text { 2000 US\$ }\end{array}$ & \%GDP & $\begin{array}{c}\text { Government } \\
\text { Health expend. } \\
\text { per capita US\$ }\end{array}$ & $\begin{array}{c}\text { \% of Total } \\
\text { Government } \\
\text { expenditure } \\
\text { On health }\end{array}$ & $\begin{array}{c}\text { Life } \\
\text { expectancy } \\
\text { at birth } \\
2002\end{array}$ \\
\hline Indonesia & 20 & $2.8 \%$ & 5 & $3.5 \%$ & 68 \\
Malaysia & 294 & $3.3 \%$ & 156 & $6.1 \%$ & 72 \\
Myanmar & 28 & $2.2 \%$ & 4 & $1.2 \%$ & 59 \\
Philippines & 169 & $3.4 \%$ & 80 & $7.0 \%$ & 69 \\
Singapore & 933 & $3.6 \%$ & 329 & $6.7 \%$ & 80 \\
Thailand & 237 & $3.6 \%$ & 138 & $11.8 \%$ & 70 \\
Canada & 2,541 & $9.9 \%$ & 1,452 & $15.2 \%$ & 80 \\
France & 2,416 & $9.3 \%$ & 2,061 & $13.4 \%$ & 80 \\
Japan & 2,827 & $7.6 \%$ & 2,298 & $16.1 \%$ & 82 \\
United Kingdom & 1,859 & $7.3 \%$ & 1,442 & $14.6 \%$ & 78 \\
United States & 4,539 & $13.1 \%$ & 2,017 & $18.2 \%$ & 77 \\
\hline
\end{tabular}

Source: World Health Report 2005, Annex tables1,5,6

The United States of America sets the upper boundary on expensive health care with its fee for service system. The United Kingdom, France, and Canada spend less respectively on health and medical care, but have better health status while utilizing less of their GNP on the health and Medical sector.

None of the ASEAN countries spend nearly as much for health care in terms of European or North American countries, and Singapore the same life expectancy as Canada and France, and three years higher than the United States

As can be seen in figure 1 below, Indonesia's expenditure for health and medicine is quite low for its level of economic development. This is even more paradoxical when one considers that relative good health status of the country in light of this low level of expenditure. The life expectancy is higher, risk of infant mortality, and probability of dying is much lower than many other developing countries, including South Asia, almost all of African, and several other countries in SE Asia such as Myanmar, Cambodia and Laos. The health status of Indonesia is very close to that of the Philippines which spends 8 times more for health and medical care than does Indonesia. There is obviously many factors besides the health care system contributing to the health status of Indonesia, and that the health care investments are effective. 


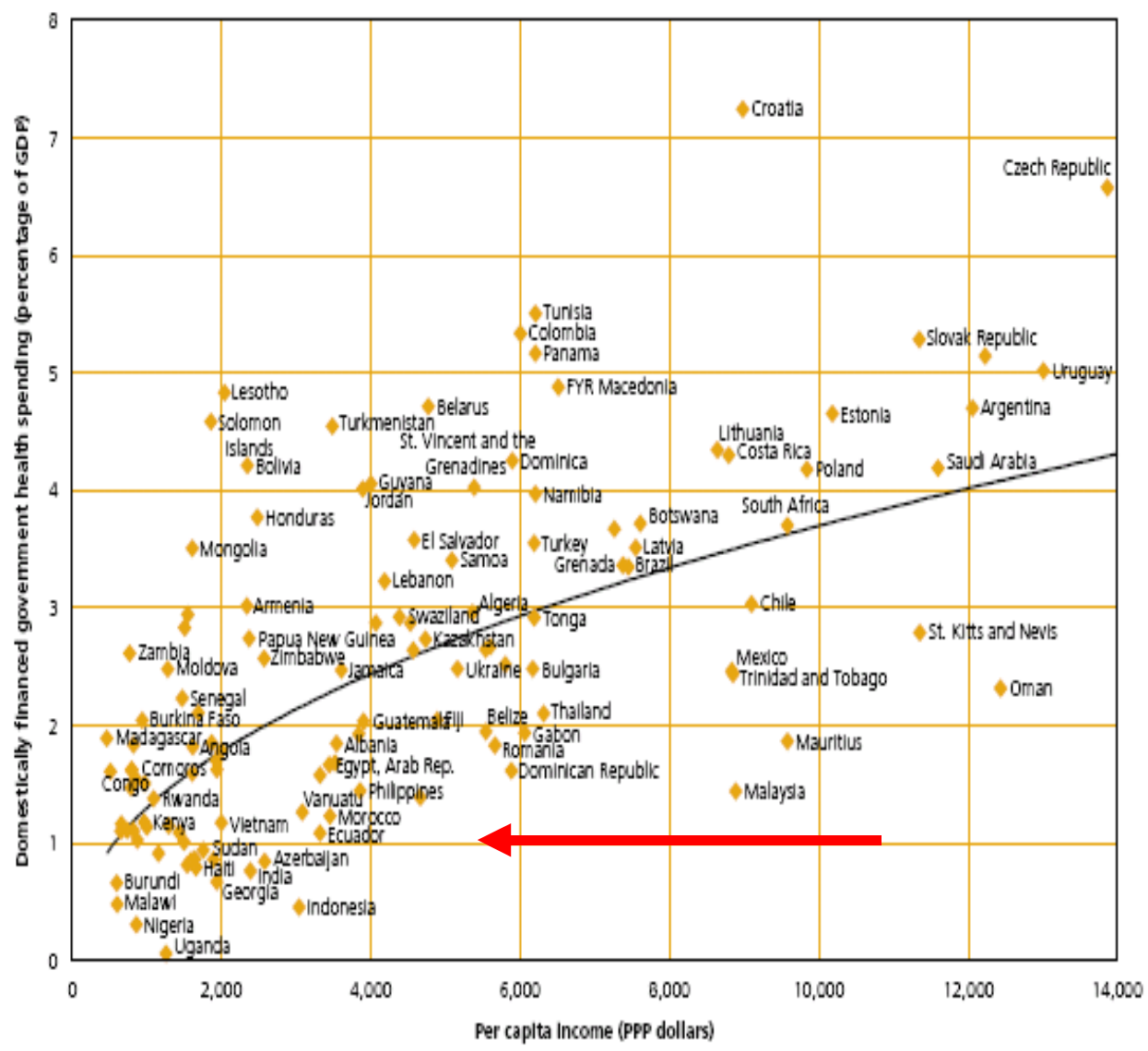

Not only does not the government invest low levels of resource in health in Indonesia, but consumers also do not investment much in the way of medical and health care. As can be seen in Table 2 in various DHS provinces consumers spend 2 to 8.2 more on tobacco than they do on health services within a year, and tobacco is only a small proportion of total outlays. The most expensive component is of course consumption of food, which is one of the determinants of good health.

Table 2

Household expenditures in DHS provinces on Health Care, Food, and Tabacco Susenas 2004

\begin{tabular}{|l|c|c|c|c|}
\hline \multirow{2}{*}{} & \multicolumn{2}{|c|}{ Annual Per Capita Household expenditure (rp) } & \\
\cline { 2 - 3 } & health & food & $\begin{array}{c}\text { tobacco, sirih, and } \\
\text { alcohol }\end{array}$ & $\begin{array}{c}\text { tobacco compared to } \\
\text { health }\end{array}$ \\
NAD & 28,741 & $1,394,100$ & 234,452 & 8.2 \\
Riau & 46,191 & $1,934,898$ & 342,843 & 7.4 \\
Bengkulu & 42,493 & $1,349,358$ & 202,894 & 4.8 \\
Bali & 85,283 & $1,676,273$ & 172,217 & 2.0 \\
\hline
\end{tabular}




\begin{tabular}{|l|l|l|l|l|} 
North Sulawesi & 40,705 & $1,641,144$ & 267,012 & 6.6 \\
Central Sulawesi & 38,604 & $1,320,842$ & 227,426 & 5.9 \\
South East Sulawesi & 24,638 & $1,352,334$ & 191,007 & 7.8 \\
\hline
\end{tabular}

The decentralization laws 22 and 25 of 1999 which took effect in 2001 were considered to be a potential threat to the health status of Indonesia. It was feared by many health development specialists both in Indonesia and in various donor agencies, that decentralization of funding and budgeting would actually reduce the amount of money going into the health sector by the government leading to a deterioration of the quality of services. At the time of decentralization, the economy of Indonesia had not yet recovered from the monetary crisis of 98 and the political instability of 99 . Moreover the social safety net developed as a response to the monetary crisis was schedule to be finished approximately as decentralization was suppose to start.

Against this background the World Bank, and the Asian Development Bank pledged loan money support to various provinces and their respective districts during the initial period of decentralization to insure that there would be sufficient funds to continue with health and educational benefits for the poor, and strategic capital investments to maintain and improve quality of medical and health promotion activities.

\section{OBJECTIVE}

We will review various measures of health care utilization and health status across consumption quintiles before and after the introduction of decentralization, to try and determine what the initial impact of decentralization has been, and have further compared changes in health status over decentralization, and between various areas receiving various types of support (or no support what so ever), with different packages of health sector reform intuitives to look at the changes in health status associated with various endeavors.

\section{METHODS AND MATERIALS}

The bureau of statistics annually collects mid census data from a randomized multi-stage sampling frame on expenditure patterns, health utilization, and every three years on health and nutritional status. This is called the SUSENAS survey.

We have utilized the expenditure and health core of the 2000 and 2004 SUSENAS household expenditure and health core to review changes in reported utilization of morbidity, self treatment, out patient and inpatient care, birthing patterns before and after the implementation of Decentralization. Child hood nutritional status uses data from the 1989, 1992, 1995, 1998, 1999, 2000, 2001, 2002, 2003 SUSENAS.

Population weighted analysis was carried out using SpssPC (rev 12). Statistical analysis was done using chisquare and students t-test. However in a population weighted analysis most differences are significant, even with extreme assumptions of design effect.

\section{RESULTS}

\section{Morbidity and Utilization of Health Care, 2000 and 2004}

In reviewing the reported morbidity patterns in Indonesia between 2000 and 2004 one can see an increase in the number of people reporting to have been ill in the previous month. From $24.6 \%$ of the population having been ill the previous month in 2000 , it increased to $26.5 \%$ of the population reporting illness in the previous month in 2004. The health of Indonesia although improving in terms of life expectancy, and reduction of infant mortality But symptoms of colds, and fevers remain similar between the two time periods.

Of the $24.6 \%$ that report being ill in the preceding month, only $40 \%$ of them (or $10.4 \%$ of the total population) reported seeking outpatient or inpatient care. The majority of 
those that are ill self treat, or do not sick treatment outside the household when ill. It is interesting to note the increase in inpatient care between 2000 and 2004 (a 75\% increase), showing an increasing demand in Indonesia for inpatient services.

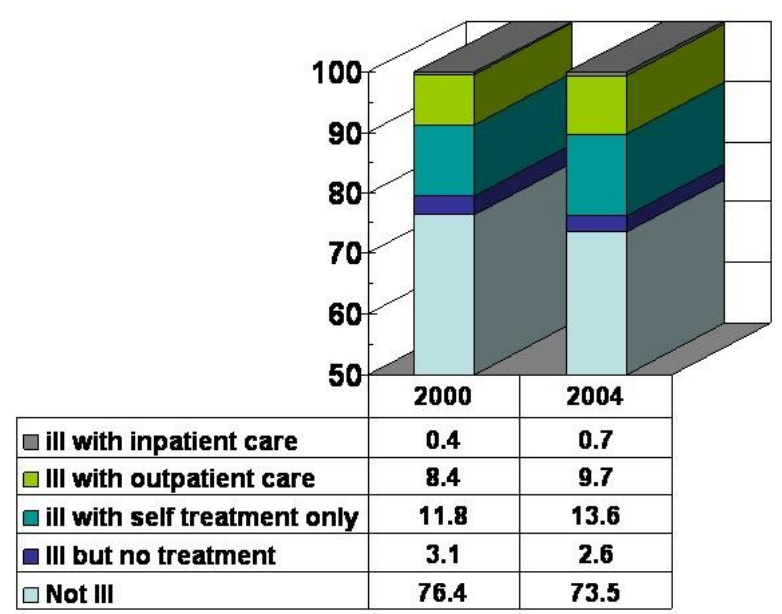

Patterns of Health care Utilization by Quintile of Household Expenditure

Household expenditure for all food, capital good, durable good, rent, goods and services procured in the last year were calculated, and household divided into quintiles depending on their expenditure level. Quintile 1 represents the lowest level of expenditure (and is assumed to be the poorest). Quintile 5 represents the highest level of expenditure, and represents the most financially well off. While morbidity rates were relatively stable across quintiles, those families in quintile 5 were $35 \%$ more likely to seek outpatient care, and 4.6 times more likely to seek inpatient care than those in the lowest quintile of expenditure.

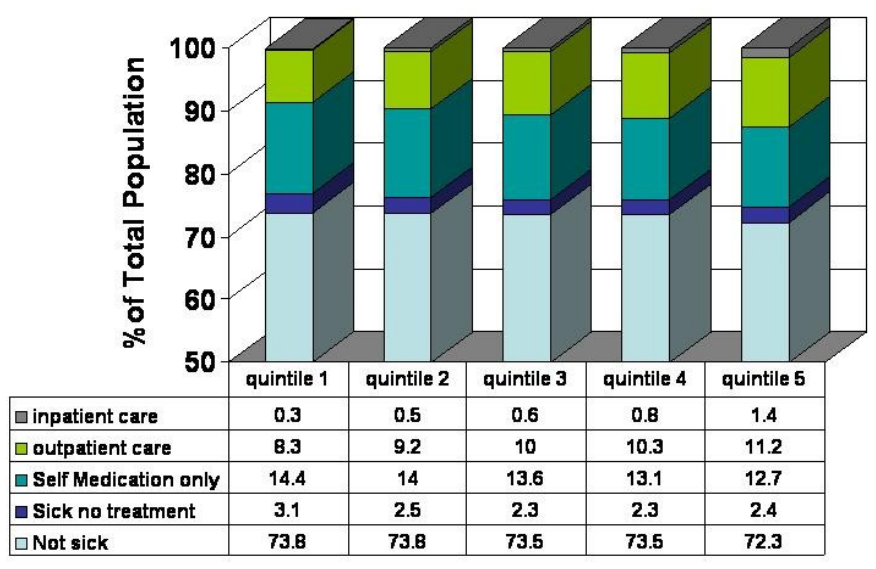

\section{Birthing Patterns}

Births assisted by trained health personnel appear to have increased between 2000 and 2004.
In $200063.5 \%$ of all births were reported to be assisted by trained health personnel. In 2004 that had increased to $71.5 \%$ of the population. However as can be 
seen on the following chart was higher in those provinces supported by the DHS-1 project that in the rest of Indonesia. This is particularly encouraging as the DHS-1 provinces are more smaller isolated smaller provinces with more dispersed populations, as compared to the major population centers of Java

\section{Births assisted by trained health personnel Susenas 2000 \& 2004}

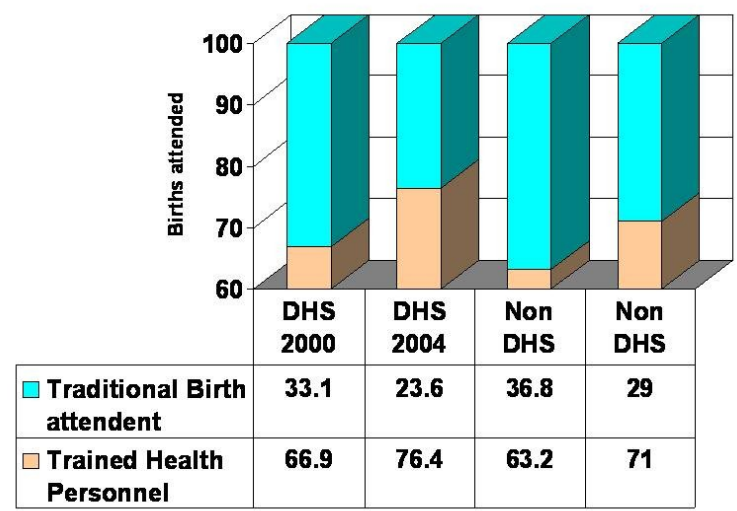

This increase in utilization of birthing services was also seen in the overall utilization of outpatient services. Which a $30 \%$ increase in government supported outpatient services in the DHS provinces, as compared to the non-DHS provinces. This suggests that the rehabilitation of health care facilities and the procurement of equipment increased the consumer demand for the government provided medical and health services.

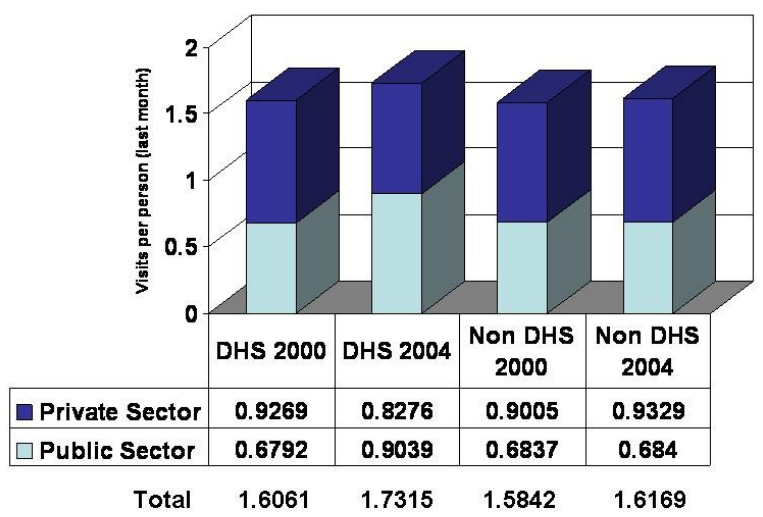

\section{Health Status Changes}

Three commonly used mortality measure of health status are infant mortality rate, maternal mortality rate, and under five mortality rate. On all three parameters there have been improvements between 2000 and 2004. In terms of Infant mortality, there has been a reduction from 45 to 35 . In looking at longer range trends it can see that infant mortality risk reduction had leveled off during 
the late 1990's, but after decentralization made a rapid and significant decrease.

Indonesian Infant Mortality Rate, 1977 to 2004

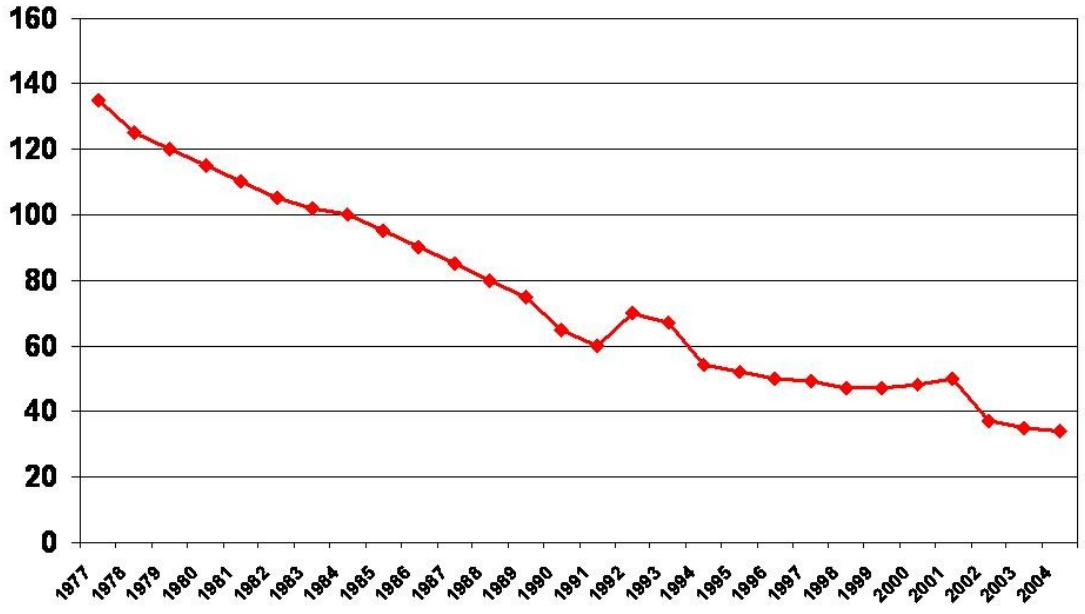

Indonesian Maternal Mortality Risk 1980 to 2004 (and trend to 2015)

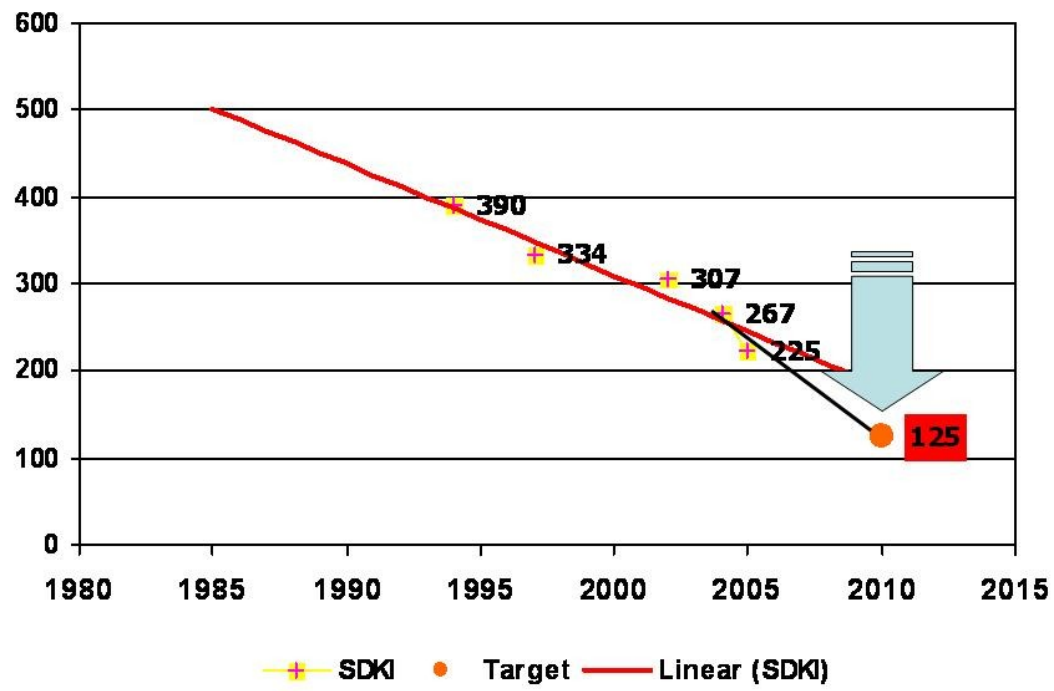

Material mortality risk also reduced after decentralization. This is a more difficult health to measure precisely, but using reported figures it appears that from 320 deaths per 100,000 live births in 2000 the MMR reduced to around 267 deaths per 100,000 live births in 2004. This would parallel the increase in births assisted by trained health personnel.

Under five mortality also contains infant mortality and is also been reduced during the time period covered by decentralization. What is interesting to note that Indonesia has made much more progress in the 1990's on under five mortality $\left(7^{\text {th }}\right.$ highest rate of improvement), as compared to improvement of nutritional status. Moreover in comparing the rates of improvement in under five 
mortality between 1990 and 1980's it appears that much more progress in the 90's that in the 80's (when there was significant improvement in nutritional status and micro- nutrient status). Indonesia improvement in nutritional status is much lower level in the 1990's than its improvement in mortality risk among under fives.

\section{Indonesia is doing well in reducing $<5$ Mortality but not as well in improving growth faltering}

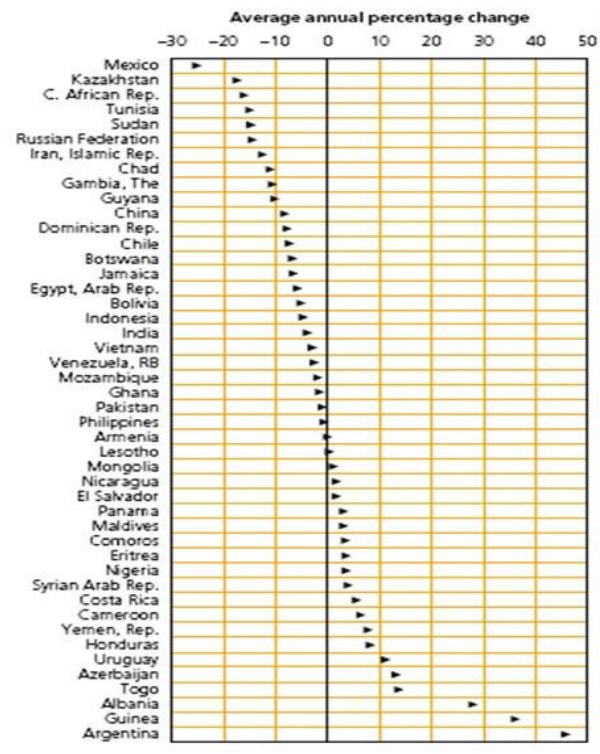

\section{Nutritional Status}

The nutritional status of the children of Indonesia have not improved with decentralization. In fact if one focuses on severe underweight, it can be seen in table three below that there has been $12 \%$ increase in severe underweight children between 2000 and 2004. This is partly an affect of the fact that the nutritional status of

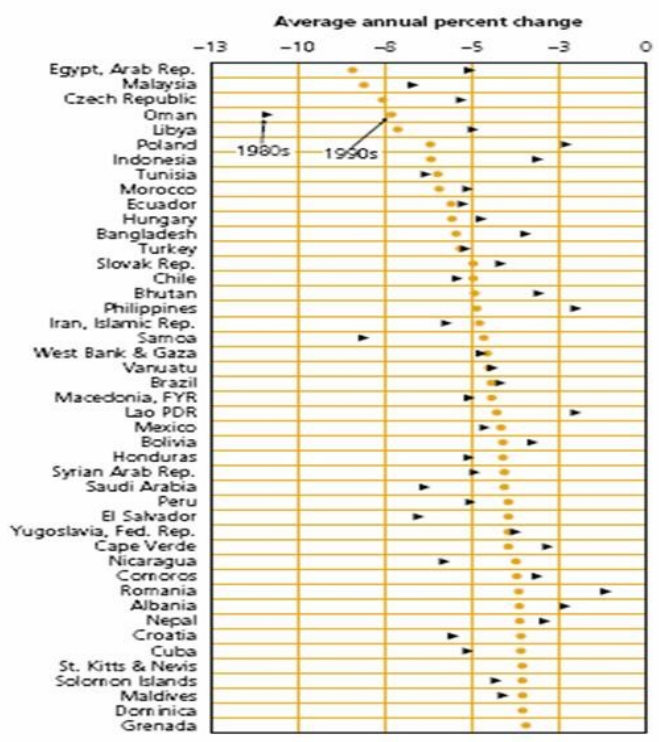

Indonesian children actually improved during the monetary crisis, so that if one makes a more "fair comparison" of nutritional status between 1998 and 2003 it appears that severe malnutrition has gone done. No nutritional status data was collected in the Susenas 2004 data set. But in 2005 the rates of severely underweight have increased to $8.8 \%$.

Table 3

Rates of Malnutrition in Indonesia 1989-2005 (Weight for age < -2 SD, and < -3SD)

\begin{tabular}{|l|l|l|l|l|l|l|l|l|l|l|}
\hline & 1989 & 1992 & 1995 & 1998 & 1999 & 2000 & 2001 & 2002 & 2003 & 2005 \\
\hline $\begin{array}{l}<-2 \text { SD } \\
\text { (Underweight) }\end{array}$ & $37.5 \%$ & $35.5 \%$ & $31.6 \%$ & $29.5 \%$ & $26.4 \%$ & $24.6 \%$ & $26.1 \%$ & $27.3 \%$ & $27.5 \%$ & $28.0 \%$ \\
\hline $\begin{array}{l}<-3 \text { SD } \\
\text { (Severely } \\
\text { underweight) }\end{array}$ & $6.3 \%$ & $7.2 \%$ & $11.6 \%$ & $10.5 \%$ & $8.1 \%$ & $7.5 \%$ & $6.3 \%$ & $8.0 \%$ & $8.3 \%$ & $8.8 \%$ \\
\hline
\end{tabular}

Source: Susenas Data set, Nutritional Status Component, 1989-2005.

The improvement of nutritional status during the monetary crisis is a phenomena 
commented on by several international agencies ${ }^{4}$. This temporary $20 \%$ improvement is often credited to the massive food aid component of the social safety net, but a reduction of birth rate during the early part of the monetary crisis among the lowest quintile population might have also contributed to this improvement in national nutritional status. 


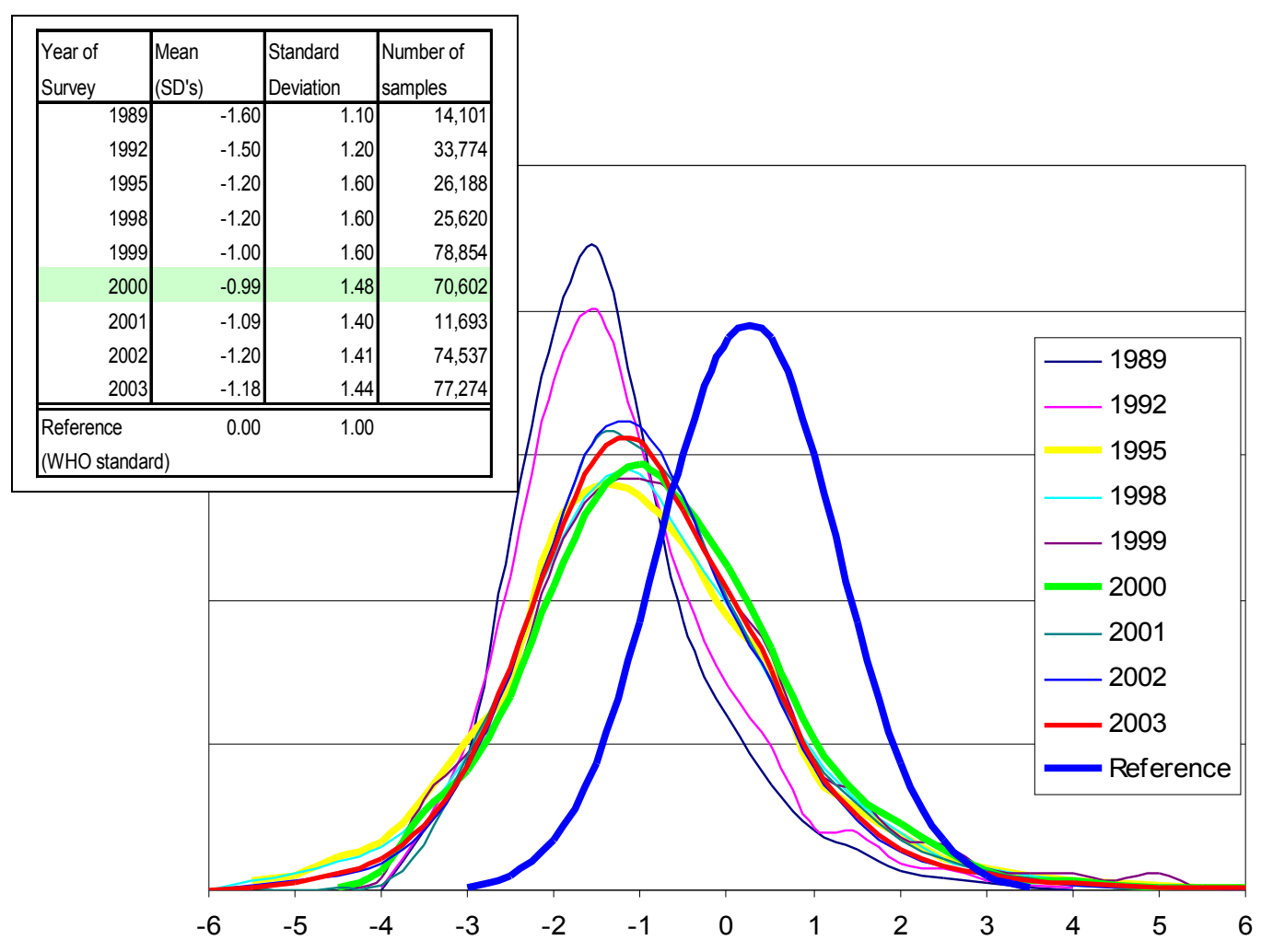

Growth faltering reduction in 2000 appears across all age groups in preschool children, but this improvement was immediately reverted to pre-crisis levels by 2003.

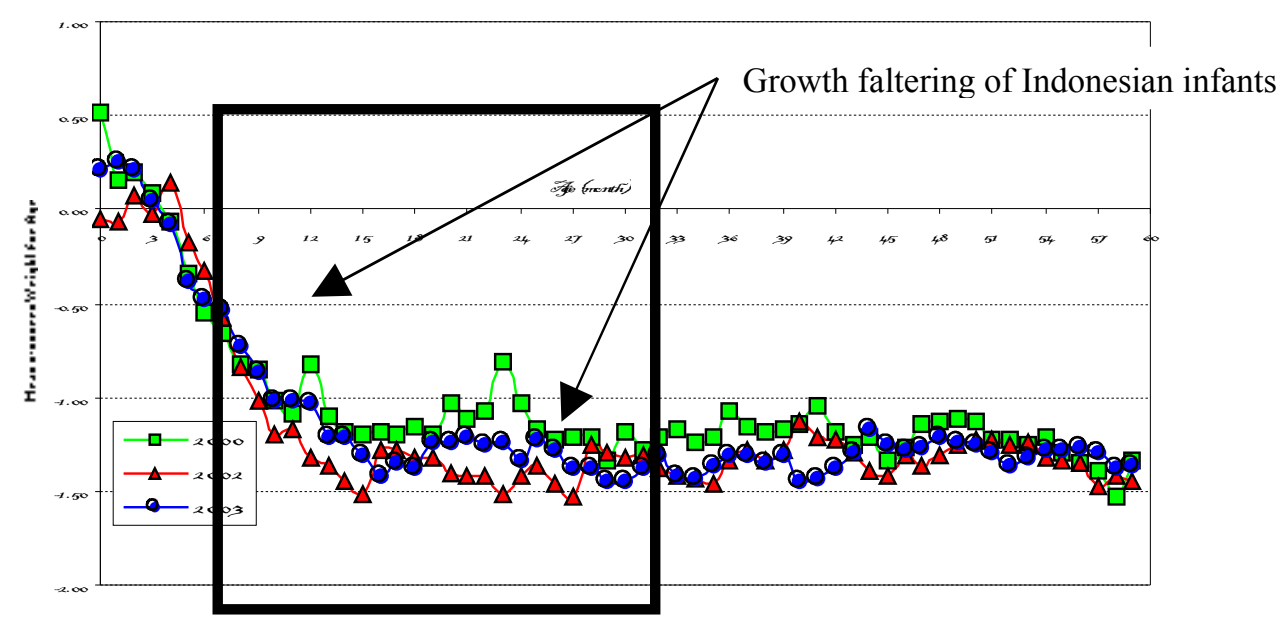

DISCUSSION

Investment in health care historically has never been a priority of either the government or the consumers of Indonesia's. 
Indonesia both before and after decentralization has had one of the lowest levels of investment in health care in the Asean region, if not the world.

The health status of Indonesia is far better than one might expect given the low levels of resources committed to it by either the government or the consumers. The changes in health status during decentralizations are most likely due to policies established prior to decentralization. Moreover the determinants of health are not primarily funding in the health care system, but are perhaps more linked with other sectors such as education, employment and income.
Moreover there is marked difference between the highest and lowest level of income in where outpatient medical services are sought, and how those services are paid for. As can be seen in the figure below those in the lowest two level of income primarily utilize government provided public service centers, health centers and sub health centers, while those in the highest level of expenditure tend to utilize private higher quality sources of outpatient care. But even with that generalization, it should be noted, that some in the lowest level of expenditure (quintile 1 and 2) utilize private sector services, and some of those in the highest level of income also seek care at government health centers and sub health centers.

\section{Utilization of Private and Public Health Services for Outpatient medical services by expenditure quintile Susenas 2004 in DHS Provinces}

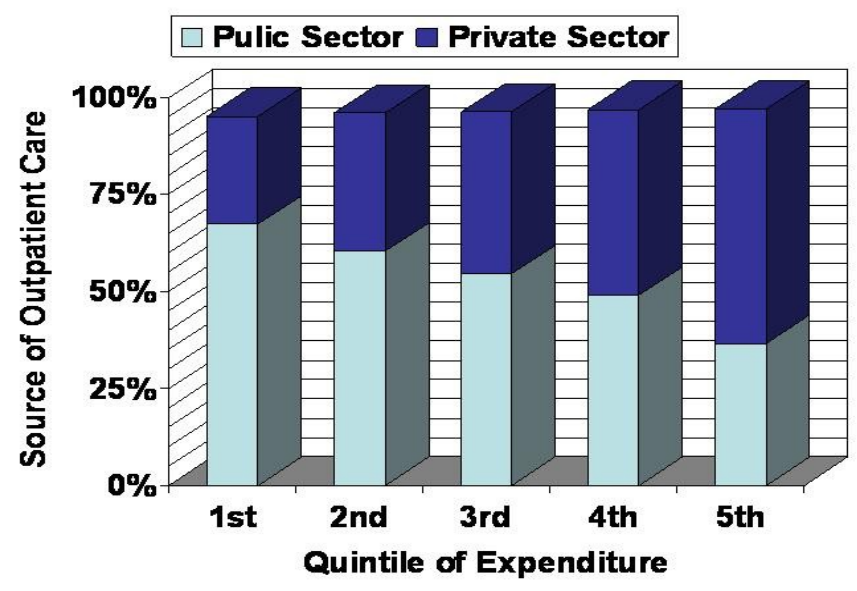


Financing Outpatient Visit to Public Medical Service by Quintile of Expenditure - 2004 - Susenas - DHS - Province

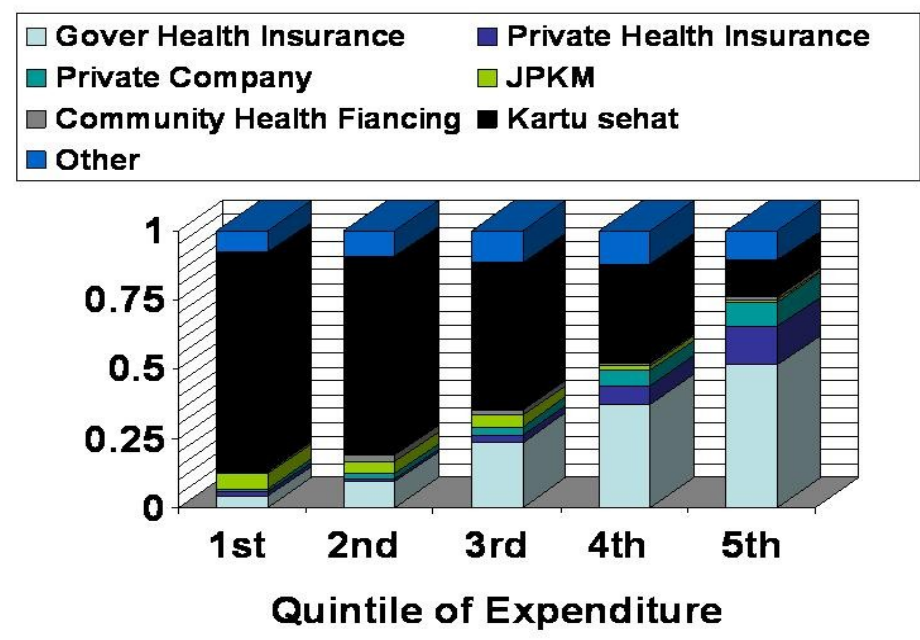

Financing of health services follows similar patterns. During 2004 there was a health card issued by the local government, and services were financed by the national government with the health social safety net. As can be seen most of those in the lowest two expenditure quintiles primarily to utilize these sources of outpatient visits. However it appears that health cards were also used the top two quintiles to provide for out patient services. It is also interesting to note that some within the lowest quintile had access to government health insurance.

\section{CONCLUSION}

Decentralization does not appear to have had any negative consequences in terms of deterioration of the collective health status of Indonesia. Indeed, several indicators appear to be improving more rapidly after decentralization than before.

Moreover in those provinces where socialization of health sector initiatives were introduced using additional multilateral support, there appears to have been an additional increase in the utilization of health services, assisted birth, and improvement in health status.
Pre-school children's risk of malnutrition appears to have stayed the same over the last 10 years except for a slight improvement during the monetary crisis.

It appears that essential to improving health status is increasing government expenditure, and increase consumer demand for government health services.

\section{REFERENCES}

1. Allen, L.. Gillespie, S. "What Works? A review of the Efficacy and Effectiveness of Nutritional Interventions." Asian Development Bank 2001.

2. Berman, $P$ editor "Health Sector Reform in Developing Countries. Boston 1995.

3. Berer M. Health Sector Reformas: implication for sexual and reproductive health services. Reproductive health matters 2002:10:6-15.

4. Matlin, S. Global Forum for Health Research, Global Forum Update on Health Research for Health Volume 2. Pro-book Publishing Limited 2005.

5. Ministry of Health (Indonesia) Basic Health Center Data from 2004. 
6. Newbrander editor Private Health Sector Growth in Asia. John Wiley and sons, 1997 London.

7. Roberts, Hsiao, Berman, Reich Getting Health Reform Right. Oxford University Press, New York. 2004.

8. WHO Indonesia: Sub national Health System Performance Assessment BPS, Jakarta.

9. World Bank; World Development Report: 2004 Making Services Work for Poor People, Oxford Press, New York.

10. World Bank. World Development Report: 2006 Equity and Development, Oxford Press, New York.

11. World Bank. The Millennium Development Goals for Health. Raising to the Challenges. World Bank 2004, Washington.

12. World Bank. Reposition Nutrition as central to Development. World Bank 2006 Washington. 